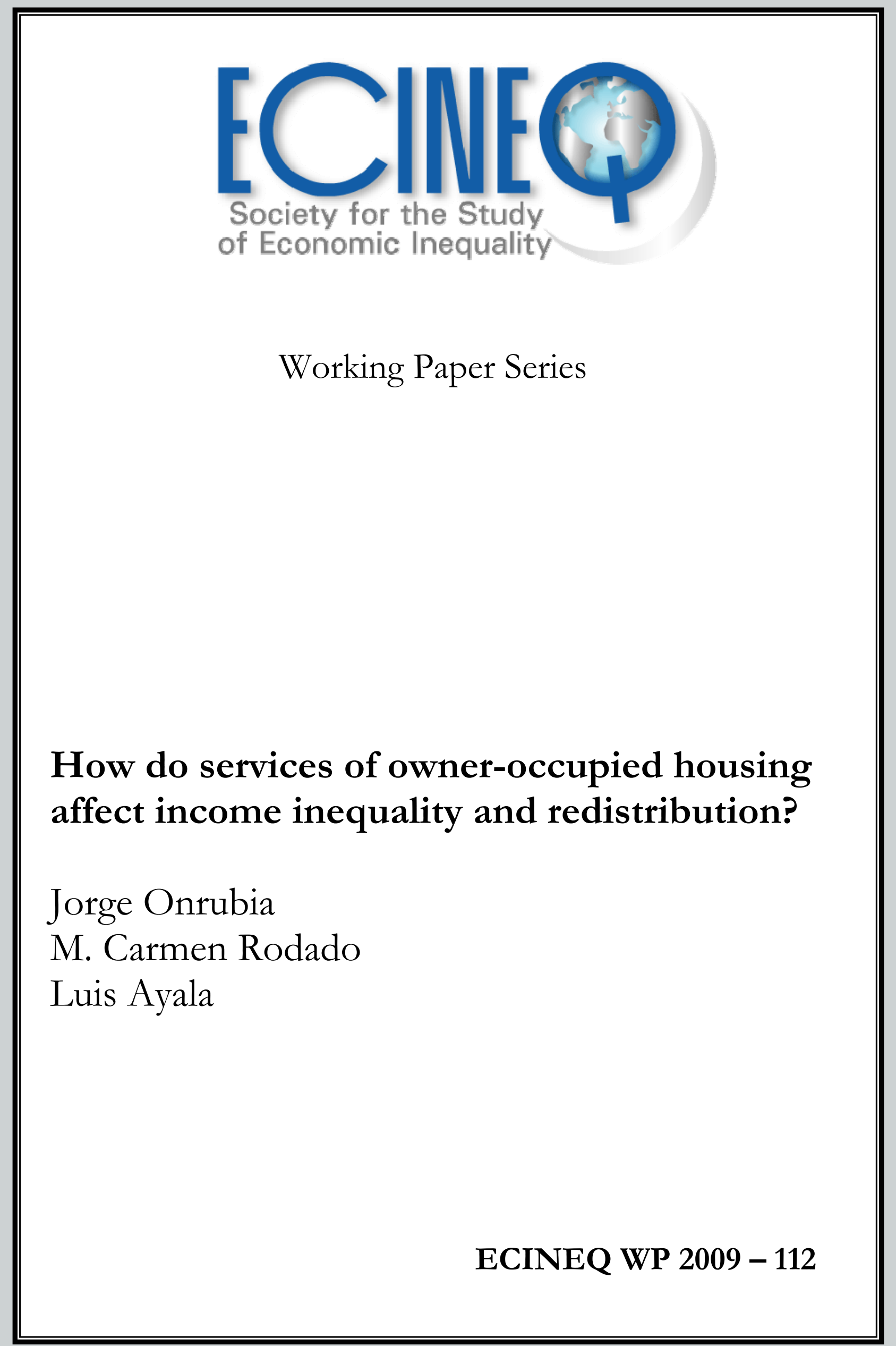




\title{
How do services of owner-occupied housing affect income inequality and redistribution?*
}

\author{
Jorge Onrubia \\ Universidad Complutense de Madrid \\ M. Carmen Rodado \\ Universidad Rey Juan Carlos \\ Luis Ayala ${ }^{\dagger}$ \\ Universidad Rey Juan Carlos
}

\begin{abstract}
This paper aims at analyzing the redistributive impact that the inclusion of imputed rental market value of owner-occupied housing would have when quantifying ability to pay, rather than the legal imputation that considers cadastral values. We consider the Spanish Personal Income Tax as reference, due to the differential treatment that provides to this type of income, together with the higher percentages of ownership for primary residence in Spain. The analysis is carried out through a micro-simulation exercise in which different scenarios are proposed. Our results show that the measurement of income including market value incomes resulting from actual or potential use of significantly modifies income inequality and IRPF progressivity and redistribution.
\end{abstract}

Key words: owner-occupied housing services, inequality by income sources, personal income tax, progressivity, redistribution

JEL Classification: D31, D33, H23, H24

\footnotetext{
* Jorge Onrubia and M. Carmen Rodado thank financial support provided by Ministerio de Educación y Ciencia (SEJ2006-04444). Luis Ayala thanks financial support from Ministerio de Educación y Ciencia (SEJ2007-67911-C0303). We also thank participants at Seminario de Investigación del Instituto de Estudios Fiscales, I Simposio sobre Reformas Fiscales y Microsimulación (Universidad de Vigo, REDE) and XV Encuentro de Economía Pública (Universidad de Salamanca) for helpful discussions and comments. The usual disclaimer applies.

† Addresses of correspondence: Luis Ayala, Facultad de Ciencias Jurídicas y Sociales, Universidad Rey Juan Carlos, Paseo Artilleros s/n, 28032 Madrid, SPAIN, luis.avala@urjc.es, Fax: +34 915532796
} 


\section{Introduction}

There is general agreement that an income concept must include both monetary and non-monetary components, since both cash and non-cash income determine the economic well-being of households (Smeeding et al., 1993). Nevertheless, the inclusion of non-cash income faces a lot of measurement difficulties, which explains that incomes from services of consumer durables are often omitted in the studies on income distribution, consumer price indexes or macroeconomic indicators (Katz, 1983). In this respect, imputed rental value of owner-occupied represents a paradigmatic case which has captured on rare occasions the attention of the literature on income inequality ${ }^{\ddagger}$.

The treatment given to in-kind income in the definition of ability to pay in personal income tax is a classic topic in Public Finance theory. In most countries, however, personal income taxes do not uniformly tax the whole income obtained by the taxpayers, due to very different reasons ${ }^{\S}$. The difference in tax treatment according to the income source or the way it is received implies a violation of the principle of horizontal equity, at least from a classic understanding of this notion ${ }^{* *}$. A clear example of this difference is found in the distinct intensity by which monetary and non-monetary income are taxed. This issue can be crucial for a better understanding of the extent to which these frequently progressive taxes are modifying the structure of income inequality.

The way non-monetary income must be considered is usually a widely debated issue in income tax reforms ${ }^{\dagger \dagger}$. Real-estate income resulting from owner-occupied housing is a distinctive case. Different economic arguments based on tax principles, which are at times opposed, as well as inevitable reasons of political calculation, explain the controversy usually surrounding the taxation of this type of non-monetary income. Being a common issue in many countries, Spain stands out as one of the most interesting cases. The differential treatment which the Spanish Personal Income Tax (from now on, IRPF) provides to this type of income, together with the remarkable importance of investment in residential housing in

\footnotetext{
‡ Some exceptions are Lerman and Lerman (1986), Yates (1994) and Buckley and Gurenko (1997) and Smeeding et al. (1993).

$\S$ Goode (1975) provides an attractive formulation on the global concept of income extending the classical definition of Haig-Simons.

** See Shoup (1969) and Musgrave (1990).

†† See OECD (2006).
} 
Spain and the higher percentages of ownership for primary residence are arguments that justify to focus on this issue in a country like Spain.

Real estate income receives specific treatment in the IRPF through practically all the elements used in its design: criteria for measuring taxable income, certain assumptions of partial or total exemption, different tax rates and tax credits ${ }^{\ddagger}$. In the especial case of nonrented owner-occupied housing, Act 18/1991 -which regulated the IRPF from 1992 to 1998imputed an in-kind return by the application of a rate to the cadastral value $e^{\S \S}$. The debate on the limits of this procedure to reflect ability to pay is the main motivation of this paper ${ }^{* * *}$. In particular, this paper aims at analyzing the redistributive impact that the inclusion of imputed rental market value of owner-occupied housing would have when quantifying ability to pay, rather than the legal imputation that considers cadastral values.

The analysis is carried out through a micro-simulation exercise in which three different scenarios are proposed. In the first one, the procedure set in the IRPF regulation is considered, while in the second and third this legal imputation is replaced with an estimate of the in-kind return in terms of market value. In the second scenario, a change is made maintaining initial tax liability, whereas on the third scenario tax liability is recalculated by adding the new returns at market value to the tax base. Taking as reference the results obtained in these three scenarios, we also measure the extent in which the treatment given by the IRPF to this income has affected income inequality changes. The period we use covers from 1992 to 1998, years of the enforcement of Act 18/1991. ${ }^{\dagger \dagger}$

The structure of the paper is as follows. After this introduction, the second section addresses the discussion on the concept of personal ability to pay and taxable income, with special attention to non-monetary income. The third section introduces alternatives of income imputation income for owned-occupied housing, while fourth section includes the empirical analysis and its results. Concluding remarks are presented in the final section.

\footnotetext{
\# Ayala, Onrubia and Rodado (2006) provide a detailed analysis on the differential treatments in the Spanish IRPF structure by income sources.

$\S \S$ Cadastral value is an administrative record of the housing price which is used as a base for fiscal purposes.

*** United Nations (1968) recommends including housing service in the statistics of household income.

$\mathrm{H+T}$ This period selection is due to the availability of information in IRPF records of cadastral value of all nonrented owned-occupied housing. From 1999 there is no imputation of income for primary residence.
} 


\section{Non-cash income and ability to pay in personal income tax}

In most OECD countries, personal income tax is the main figure of the tax system, not only in terms of total revenues but also in socio-political relevance. To a great extent, this position results for the suitability of its object of taxation -income- to assess taxpayers' ability to pay. This also allows for its utilization as an instrument for reaching redistributive goals.

The measurement of taxpayers' ability to pay through income earned in a year requires defining clearly and precisely the different types of taxable income. However, as unrealistic as it may seem, identifying the concept of income in the design of personal income taxes is a complex task. Regulations in different countries usually set forth in a higher or lower range itemized assumptions of taxable income. The variety of income sources and the taxpayers' own strategic behaviour, tending to artificially modify the characterization of each taxable fact, seriously hinders possibilities of this type of close relationships of constitutive assumptions of taxable income.

From an academic perspective, the most frequent method of assessing the extent to which income tax appropriately considers ability to pay is to compare its definition with the most widely accepted measure of what income is considered to be in economic terms. In this sense, the concept of economic income traditionally chosen in public finance theory is the one identified in the definition by Haig (1921) and Simons (1938) (from now on H-S) ${ }^{\ddagger \neq}$. This concept was initially introduced by von Schanz (1896), and further developed in American public finance literature by Robert M. Haig, for whom economic income is the monetary expression of the net increase of individual economic ability between two moments in time. Later, this notion was completed by the concept of "full income" proposed by Henry Simons.

A first consideration regarding the H-S definition is that the inclusion of the different types of income does not require monetary materialization for collection. This is the case of in-kind income, such as employers' contributions to pension plans, insurance subscriptions in favour of employees, workers' use of company houses or cars, free or low price utilization of staff canteen, vouchers for any type of consumption, subsidy of financial expenditure or

\footnotetext{
非 Sunley (1977) provides an interesting discussion on the concept of economic income given by Haig-Simons and their notion of the legal definition for tax base of personal income tax.
} 
acquisition of any good or service as return of a financial investment. Including these items into the legal definition of taxable income proves complex, especially in those cases where there is no predefined monetary value. Indeed, the high administrative costs of quantifying these types of income lead either to its exclusion in the tax base on many occasions, or to its estimate through indexation methods.

On the other hand, social transfers provided by different public administrations -such as public pensions, unemployment benefits and other social benefits-, to the extent they imply increases in consumption capacity, constitute additional sources of economic income $^{\S \S \S}$. Capital gains -whether or not realized- constitute increases in the value of households' assets and, consequently, they are types of income that could be considered economic income ${ }^{* * * *}$.

Finally, one of the most contentious components of economic income is in-kind income resulting from utilization of consumer durables. A particular case of this type of income is housing services of owner-occupied housing, be it as primary or secondary residence $^{\dagger+\dagger \dagger}$. The value of these services could be understood, as pointed out by LópezGarcía (2001), as a "notional” rent self-provided by owners that is self-consumed. An analogous interpretation is that of “opportunity cost” suggested by Rosen (2005), in which the monetary value for these services would be determined by the income lost by owners when opting for not renting their houses ${ }^{\ddagger \neq ⿰ 扌 \ddagger}$. The key issue in both interpretations is an increase in the ability to pay derived from the potential or actual use of the services provided by owner-occupied housing. This greater ability to pay can be valued by comparing it with that of an individual who with same monetary income lives in a rented house with similar characteristics.

The treatment in personal income tax of this imputed income for actual or potential use of owned-occupied housing has been and is subject of controversy ${ }^{\S \S \S \S}$. The difficulty for

\footnotetext{
$\S \S \S$ However, in-kind consumption, free or at prices significantly lower than the market ones, such as health and education does not tend to be considered as economic income, since it is widely accepted that they are intended to maintain or increase the worker's capacity for generating labour income.

${ }_{* * * *}$ However, to the extent that it is difficult to measure property gains and losses, taxation is usually postponed until both are realized, usually by way of transmission of assets.

$\mathrm{t+T+}$ Usually, the notion of secondary housing also includes personal property which is owned but not occupied by its owners.

$\neq \# \#$ This income should be considered in terms of net rents. In other words, gross rents minus maintenance expenses, including amortization as well as taxes (Poterba and Sinai, 2008).

$\S \S \S \S$ A recent discussion on the imputation of this income can be found in Poterba and Sinai (2008).
} 
determining the quantity that should be imputed at market values for equivalent rents is combined with the need to periodically update cadastral values ${ }^{* * * *}$. Likewise, the high level of expenditures related to mortgage interest gives rise to a significant number of taxpayers those with running loans- whose net returns are negative. Finally, reasons of political calculation must be noticed, especially those which take into account the scarce visibility that these income flows and its subsequent impact over the tax burden have for taxpayers. These circumstances have led in the last decades to a reduction in imputed amounts in many countries. In some cases, they are no longer included in taxable income. A revision of the current situation in various OECD countries is provided in Table A.2 from the Annex.

In Spain, Act 18/1991 maintained the criterion established since the introduction of the IRPF in the tax system in 1979, which consists of quantifying these imputed returns by applying a coefficient of $2 \%$ to cadastral values to owners or usufructuaries. In other words, this tax treatment was applied to all houses which were not rented. Nevertheless, the gradual revision of cadastral values from municipality to municipality started in 1994 by the Spanish Cadastre Office led to a modification of this coefficient since 1995. It lowered the coefficient to $1.1 \%$ (1.3\% in 1995$)$, for those houses whose cadastral values had been revised, obviously upwards. It must be taken into account that in the period of enforcement of this Act, return calculation associated to this real estate income also included the tax liability of Local Property Tax (from now on, IBI) as deductible expenses. Furthermore, in the case of primary residence, there were deductions for mortgage interest ${ }^{\dagger+\dagger+\dagger}$.

With the enforcement of Act 40/1998 in 1999, the treatment of imputed income for owner-occupied housing experienced a significant change, sustained by subsequent reforms up today. Since then, returns of the taxpayer primary residence ceased to be imputed. The same criterion of imputation was applied for the remaining non-rented housing, as in Act 18/1991, although IBI charges were no longer a deductible expense. That reform also modified the treatment of mortgage interest of primary residences, which ceased to be considered deductible expense to become -together with the amounts paid either directly or

After World War II it was not possible to update the values and, then, fear of an excessive raise in the tax burden led to many countries, such as United Kingdom and France, to eliminate the imputation of income after an experience of more than 150 years (Merz, 1977).

${ }^{+++t+}$ For individual declarations, the limit to interest deduction was 4,808 euros, for joint declarations 6,010 euros. 
through loan amortization- the basis for applying a tax credit ${ }^{\ddagger \neq \ddagger \ddagger}$. This consideration is still present in Act 46/2002 and in most recent Act 35/2006 §§§§§ $^{\text {. }}$

\section{The measurement of imputed income for owner-occupied housing}

As abovementioned, measuring ability to pay through the H-S concept of economic income entails including in the tax base of personal income tax the imputed income of actual or potential use of houses by their owners. In other words, the opportunity cost or the notional rent for non-rented houses $(N R H)$. In keeping with the general aim of this paper, we need to quantify income before tax for each taxpayer including this imputed income ${ }^{* * * * * *}$. In order to estimate this non-cash income, calculation was made on the amount that could be obtained if the taxpayer's personal property would have been rented on the real estate market. This amount can be obtained by applying the annual rate of return resulting from the rental market value:

$$
\hat{X}_{i, j}^{N R H(M V)}=M V_{i, j} \cdot \omega_{j}
$$

Imputations using original cadastral values $(C V)$ of IRPF tax returns $\left(X_{i}^{\mathrm{NRH}(\mathrm{CV})}\right)$ make possible to estimate the market value ( $M V$ ) of all properties for each taxpayer through the following expression:

$$
M V_{i, j}=\frac{\overline{M V}_{j}}{\overline{C V}_{j}} \cdot \frac{X_{i}^{N R H(C V)}}{v_{j} \cdot 0.02+\left(1-v_{j}\right) \cdot 0.011}
$$

where $i$ represents each taxpayer living in region $j$.

\footnotetext{
Applicable rates to calculate this tax credit were: a) with financing deferred in as much as $50 \%$ of the house price, $20 \%$ (25\% the first 2 years) for the first 4,507 euros and $15 \%$ for the second portion up to a maximum of 9,015 euros; b) with financing lower than $50 \%$ of the price, the only applicable rate was $15 \%$. Also, Act $40 / 1998$ introduced a temporary system for taxpayers who acquired their primary residence before April 8th 1998, and consisted of a compensation scheme for cases in which the new treatment reduced the liability tax less than the application of the prior system. Onrubia, Romero and Sanz (2004) provide a detailed analysis on the results for this compensation regulation.

$\$ \S \S \$ \S$ Act 35/2006 unified to 15\% the deduction rate by maintaining a similar absolute limit of 9,015 euros. The new Act also set up a compensation system, in this case for acquisitions of primary residence before January 20th, 2006.

******* In our approach we opted to exclude property gains resulting from growing housing prices.
} 
Given that the only individual information available in administrative data from income tax returns is $X_{i}^{N R H(C V)}$, the rest of the variables in expression [2] have to be obtained using aggregated data. For every dwelling unit, current relationship between the market value and the cadastral value is estimated through their average values per square metre in each region and year (Table 1). In the first case, information has been collected from the quarterly statistics for residential housing prices published by the Spanish Ministry of Housing. In the case of cadastral values it was necessary to combine data on average regional property values from the national Cadastre Office (2006) with information on the regional average housing size provided by the Spanish Land Registry Office (2004) ${ }^{\dagger+\dagger+\dagger \dagger}$. To estimate the imputation coefficient effectively applied in $X_{i}^{N R H(C V)}$-since from 1995 this could have been 2 per cent if the cadastral value had not been revised and 1.1 per cent $(1.3 \%$ in 1995$)$ if it had been modified-, weightings $\left(v_{j}\right)$ had been obtained for houses with non revised values and the complementary $1-v_{j}$ for the ones revised, using information provided by the Cadastre Office (Table 2).

The annual rate of return $\left(\omega_{j}\right)$ is defined for each year and region as the ratio between the average rent per square metre for residential housing and the average market value per square metre for this type of housing ${ }^{\ddagger \ddagger \ddagger \neq \ddagger}$ (Table 3). The information about average rents is reported in the Survey of Rental Housing (Ministry of Housing, 2006). Because the data from this survey were collected in the last quarter of 2006, the amounts for the period under study have been calculated using the consumer price index of rented housing. Due to the variety of both the year property was built and housing qualities and the lack of data, the option was to define the annual rate of return in gross terms -without considering maintenance expenses, property depreciation and the IBI. The significant heterogeneity found in housing prices and rents throughout the Spanish territory makes necessary to estimate these returns by regions. This option required to adopt the restrictive assumption of considering that all dwellings of

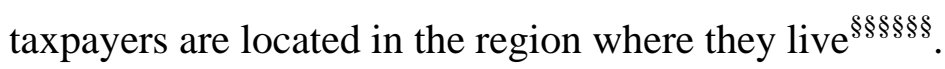

\footnotetext{
${ }^{+++++\dagger}$ From a political point of view, Spanish regions are called Autonomous Communities.

抹㧊 With this annual rate of return we intend to include the owner’s opportunity cost of non-rented housing. Therefore, this rate is not the internal rate of return "before taxes" from housing investment, since this last notion would include investment appreciation.

$\S \S \S \S \S \S$ Microdata from income tax returns do not provide one-to-one information on every house. However, in most cases taxpayers only own their primary residence.
} 
Tables 4 and 5 shows results of market value estimates of imputed income for owneroccupied housing. In table 4, the imputed average value according to Act 18/1991 is compared with the one corresponding to the alternative imputation at market value, but only for taxpayers who declared this type of income. In table 5, the comparison includes all taxpayers, regardless of whether or not they declare this non-cash income. Table 5 also includes average values of total income before tax for the two alternative imputations.

Focusing on table 4, it is observed that in the case of the cadastral value $\left(X_{i}^{N R H(C V)}\right)$, the average amount imputed by taxpayers declaring this type of income grew from 1992 to 1994, only to experience a sharp drop in 1995, even sharper than that of 1992. As from 1996, this amount increases again up to 1998, in which it reaches a similar level to the one in 1992. Although since 1994 a process of upwards revision of cadastral values began, this result was mainly due to the introduction in 1995 of a reduced imputation coefficient of $1.1 \%$ (1.3\% in 1995) to be applied to the revised cadastral values.

With regard to the income imputed in terms of market value, it is observed that the average amounts of $\hat{X}_{i, j}^{N R H(M V)}$ are significantly higher than those calculated using the cadastral value, $X_{i}^{N R H(C V)}$, as it was expected. It is worth mentioning that for $\hat{X}_{i, j}^{N R H(M V)}$ the average amount grew in 1992 and 1993 -as it happened with $X_{i}^{N R H(C V)}-$, dropped sharply in 1994 and recovered from 1995 onwards. However, in contrast to what happened to $X_{i}^{N R H(C V)}$, the average amount of $\hat{X}_{i, j}^{N R H(M V)}$ surpasses the initial amount -that of 1992- in the last two years. The significant growth as from 1996 of the two variables involved in $\omega_{j}$-housing market and rent prices- accounts to a great extent for this behaviour. 


\section{Empirical analysis and results.}

In order to analyze the distributive impact of the tax treatment of owner-occupied housing in Act 18/1991, three scenarios are proposed. The first replicates the criterion laid down in Act 18/1991, which imputation rule consists of a percentage of the cadastral value of non-rented housing. According to the calculated data, it implies a considerable underestimation of the market value for this type of return $\left(X_{i}^{N R H(C V)}\right)$. The second scenario consists of imputing this return in market values, but limiting the amount to be taxed through an exemption $\left(\hat{X}_{i, j}^{N R H(M V)}\right)$. The idea is to maintain tax liability unchanged. In the third scenario the legal imputation in Act 18/1991 is also replaced by the imputed income market values. Unlike the second scenario they are entirely included in the tax base, without exemptions, whence tax liabilities will be modified.

To the extent that the exemption considered in the second scenario is equal to the difference between the rental-market value and the resulting amount of applying the imputation rule of Act 18/1991, the first and second scenarios will be equivalent with respect to the impact on tax liability. However, the effects on progressivity and redistribution will depend on how the income before tax is defined. From an economic perspective, it seems reasonable to add these incomes at market value. The other option is using cadastral values. A fourth option could combine the income imputed in terms of market value with its total exemption only for primary residence. This scenario would be identifiable with the treatment provided by the IRPF since 1999. However, it is not possible to implement this microsimulation exercise, since the information available in the income tax returns will not reveal which portion of the imputed income corresponds to primary residence and which one to the remaining houses.

Simulations exercises have been carried out using for every year -from 1992 to 1998a sample of tax returns from Spanish Institute for Fiscal Studies' panel of IRPF tax filers. Number of taxpayers for each year is presented in Table 5. For the sake of simplicity, in joined filers' tax returns, we have assumed that there is only one taxpayer.

Having defined these three scenarios, our empirical analysis focuses first on the assessment of changes in income inequality before tax when imputed incomes at market 
values are considered $\left(\hat{X}_{i, j}^{N R H(M V)}\right)$ instead of the legal imputation $\left(X_{i}^{N R H(C V)}\right)$. For this purpose, we compare Gini indexes of income before tax under two imputation alternatives. Value market criterion (scenarios 2 and 3) yields higher income inequality before tax than the levels obtained with cadastral values (scenario 1). In respect to the incidence of market values on the redistributive effects of the personal income tax, it is observed that the result largely depends on the amount of imputed rents finally taxed. If income before tax is defined according to scenario 2, the Reynolds-Smolensky (1977) index $\left(\Pi^{R S}\right)$ falls below the one obtained in scenario 1. This redistribution loss ranges between 27.5 and 32.8 per cent. If the standard Kakwani (1977) decomposition is used,

$$
\Pi^{R S}=\Pi^{K} \cdot a /(1-a)-R
$$

it is observed that the reduction in $\Pi^{R S}$ results from both a reduction in progressivity $\left(\Pi^{K}\right)$ as well as a reduction in average effective tax rates $(a)$. Both reductions are due to the lack of changes in tax liability and a remarkable increase of ability to pay.

However, it must be noted that although this result seems to be immediate, it is not the case. As it was shown for the criterion of imputation in terms of market value (scenarios 2 and 3), inequality in income before tax was higher than the one obtained in scenario 1, which entails a progressivity reduction in scenarios 2 and 3 . Furthermore, it is worth mentioning that not only inequality of income before tax changes - measured by $G_{X}$ - but also inequality related to the concentration of tax liabilities - measured by $C_{T}$. The reason lies in the significant re-ranking in the income distribution before tax with respect to scenario 1 . This is a consequence of making a fraction of taxpayers wealthier by recognizing them a greater ability to pay from the use of services provided by their houses.

In short, when comparing scenarios 1 and 2, it is observed that the IRPF applied between 1992 and 1998 is less progressive and redistributive than what most empirical studies show, acknowledging that the taxpayers' ability to pay must include the valuation of services derived from the use of owned-occupied housing, in a similar sense to what was set forth in Act 18/1991. In other words, imputed income cadastral value means an underestimation of opportunity costs with significant distributive losses. 
What would happen if, apart from including this market opportunity cost in the ability to pay, the increase affected tax liabilities? Scenario 3 provides an alternative empirical framework to answer this question. Results show a drastic increase of the potential tax revenues. Effective average tax rates would increase between 43 and 52 per cent with respect to the ones calculated for scenario 2. This growth compensates for the sharp drop of progressivity, bringing much higher redistributive gains than in scenario 1 and, of course, in scenario 2. Nevertheless, the re-ranking effect on redistribution is still quite noticeable.

\section{Concluding remarks}

As it was posed in the introduction, the treatment in personal income tax of non-cash income resulting from the actual or potential use of dwellings by their owners is a controversial issue. On the one hand, it is not easy to determine how much income should be imputed according to market value. On the other hand, there are sociopolitical reasons, outstanding the difficulty of taxpayers to consciously include this income in their ability to pay and its subsequent tax burden effects. Nevertheless, from a public finance perspective, there is substantial agreement about the increase in ability to pay caused by potential use of services provided by owner-occupied housing.

Arguments like the opportunity cost incurred by the owners when not renting their houses -included the one that serves as primary residence- or the notional rent self-satisfied by owners lead to consider that a suitable measurement of ability to pay should include market value estimates for this kind of income, regardless of the tax treatment given by government. However, most of empirical papers which analyze income inequality and its redistribution -including those focusing on progressivity and redistributive effects of personal income taxes- does not usually consider this approach when measuring income as an indicator of ability to pay. The increasing weight of housing expenditure in the households budget invite us to consider the relevance of income related to services provided by owneroccupied housing when studying the income distribution and its changes induced by the personal income tax.

Our results show that the measurement of income before tax including market value incomes resulting from actual or potential use of this properties significantly modifies income inequality before the personal income tax application. Scenarios 2 and 3 -in which an 
imputed income at market value was included- have showed a significant increase in income inequality before tax. This result undoubtedly affects any measurement of the redistributive effect and progressivity of the personal income tax. Even accepting the possibility that the increase in the amount of imputed incomes at market values has no consequences on tax liability -scenario 2- there would be changes in net income inequality and, as a consequence, in the redistributive capacity of the income tax. In this case, the redistributive effects of the IRPF are rather lower than those estimated for the standard case (scenario 1) -imputing income of non-rented housing using cadastral values-. Nevertheless, the effects on the IRPF progressivity are not so visible. The strong reduction obtained when comparing scenario 1 with 2 is caused, to a great extent, by re-ranking due to higher income resulting from including market value incomes for those taxpayers with non-rented houses. Therefore, the possibility of increased taxation of these non-cash incomes could be an option for significantly increase the redistributive capacity of the income tax, yet exclusively resting on the growth of total revenues given the reduction in progressivity. Consequently, our results confirm the idea that the measurement of income inequality and also progressivity and redistributive effects of personal income taxes requires a definition of income before tax closer to the concept of economic income, especially with respect to the imputed income for the services of owner-occupied housing.

A tax policy recommendation that can be drawn from our results paper is related to the use of income taxes to boost the supply of rented housing. As it has been observed, from the traditional principles of tax theory the option of considering imputed income for nonrented housing could be used as a mechanism to incentive rented housing supply, always considering its appropriate design. This alternative directly acting on the owners' opportunity cost seems superior both in terms of efficiency as well as in feasibility to the proposals that with limited fundamentals and dubious applicability- recommend to introduce specific taxation of the vague concept of "non-occupied house". In this sense, one of the future extensions of this research is precisely going one step further in the design of these incentives mechanisms. 


\section{References}

Ayala, L., J. Onrubia and M. C. Rodado (2006). "El tratamiento de las fuentes de renta en el IRPF y su influencia en la desigualdad y la redistribución”, Papeles de Trabajo, 25/06. Instituto de Estudios Fiscales, Madrid.

Buckley, R. M. and E. N. Gurenko (1997). "Housing and income distribution in Russia: Zhivago’s Legacy”, The World Bank Research Observer, 12 (1): 19-32.

Cadastre Office (2006). Estadísticas Catastrales 1990-2004, Madrid: Ministerio de Economía y Hacienda. Web: http://www.catastro.minhac.es/

Goode, R (1975). The Personal income Tax, $2^{\mathrm{a}}$ ed. Washington DC: The Brookings Institution.

Haig, R. M. (1921). The Federal Income Tax, New York: Columbia University Press.

International Bureau of Fiscal Documentation (2008a). European Tax Handbook. Amsterdam: IBFD.

International Bureau of Fiscal Documentation (2008b). North American Tax Handbook. Amsterdam: IBFD.

Kakwani, N. (1977). "Measurement of tax progressivity: An international comparison”, Economic Journal, 87: 71-80.

Katz, A. J. (1983). "Valuing the services of consumer durables", Review of Income and Wealth, 29 (4): 405-428.

Land Registry Office (2004). Estadistica Registral Inmobiliaria. Anuario 2004. Madrid. Web: http://www.registradores.org

Lerman, D. and R. Lerman (1986). "Imputed Income from Owner-Occupied Housing and Income Inequality”, Urban Studies, 23: 323-331.

López García, M. A. (2001). Política impositiva, precios y stock de vivienda (Tax policy, prices and housing stock), Madrid: Instituto de Estudios Fiscales.

Merz, P. E. (1977). "Foreign income tax treatment of the imputed rental value of owneroccupied housing: Synopsis and commentary”, National Tax Journal, 30: 435-439.

Ministerio de Vivienda (2007). Encuesta sobre la Vivienda en Alquiler de los Hogares en España 2006. Madrid. http://www.mviv.es.

Ministerio de Vivienda (2008). Estadística de Precios (Price Statistics). Web: http://www.mviv.es.

Musgrave, R. A. (1990). "Horizontal Equity, Once More”, National Tax Journal, 43:113122.

OECD (2006), "Fundamental Reform of Personal Income Tax”, OECD Tax Policy Studies, 13. Paris: OECD.

Onrubia, J., D. Romero and J. F. Sanz (2004). "Compensación de incentivos a la adquisición de vivienda en la reforma del IRPF de 1999”, Revista de Economía Aplicada, 35: 105124. 
Poterba, J. and T. Sinai (2008). "Tax expenditures for owner-occupied housing: Deductions for property taxes and mortgage interest and the exclusion of imputed rental income”, American Economic Review: Papers and Proceedings 2008, 98(2): 84-89.

Reynolds, M. and E. Smolensky (1977), Public expenditures, taxes, and the distribution of income, New York: Academic Press.

Rosen, H. S. (2005). Public Finance. New York: R. Irwin/McGraw-Hill.

Shoup, C. S. (1969). Public Finance. Chicago: Aldine.

Simons, H. C. (1938), Personal Income Taxation, Chicago, IL: University of Chicago Press.

Smeeding, T. M., P. Saunders, J. Coder, S. Jenkins, J. Fritzell, A. J. M. Hagenaars, R.Hauser and M. Wolfson (1993). "Poverty, inequality, and family living standards impacts across seven nations: The effect of noncash subsidies for health, education and housing”, Review of Income and Wealth, 39 (3): 229-256.

Sunley, E. M. (1977), "Summary of Conference Discussion”, en J. A. Pechman (ed.), Comprehensive Income Taxation, Washington, DC: Brookings Institution.

United Nations (1968). A System of National Accounts, Studies in Methods, Series F, 2, Rev. 3. Department of Economics and Social Affairs. New York: United Nations.

von Schanz, G. (1896). "Der Einkommensbegriff un die Einkommensteurgesetze», Finanzarchiv, $13: 1-87$.

Yates, J. (1994). “Imputed rent and income distribution”, Review of Income and Wealth, 40 (1): 43-66. 
Table 1

Relationship between the Market Value and the Cadastral Value of Residential Housing

\begin{tabular}{llllllll}
\hline Autonomous Community & $\mathbf{1 9 9 2}$ & $\mathbf{1 9 9 3}$ & $\mathbf{1 9 9 4}$ & $\mathbf{1 9 9 5}$ & $\mathbf{1 9 9 6}$ & $\mathbf{1 9 9 7}$ & $\mathbf{1 9 9 8}$ \\
& & & & & & & \\
\hline Andalucía & 2.6458 & 2.6581 & 2.5726 & 2.5944 & 2.3746 & 2.1938 & 2.2395 \\
Aragón & 3.9076 & 3.7370 & 3.5524 & 3.5568 & 3.3560 & 2.4150 & 2.5664 \\
Asturias & 2.2173 & 2.1863 & 1.9474 & 1.9810 & 1.9153 & 1.7274 & 1.7633 \\
Baleares & 2.5388 & 2.5719 & 2.6115 & 2.5311 & 2.2811 & 2.2134 & 2.5443 \\
Canarias & 3.6186 & 3.6055 & 3.4298 & 3.3951 & 3.2890 & 2.5913 & 2.8877 \\
Cantabria & 5.5805 & 5.3362 & 5.1395 & 5.2458 & 4.7417 & 3.9862 & 4.0144 \\
Castilla y León & 6.8082 & 6.5431 & 6.2613 & 5.7648 & 4.5866 & 4.2132 & 4.2453 \\
Castilla la Mancha & 2.5917 & 2.5288 & 2.5281 & 2.5752 & 2.4710 & 2.3488 & 2.2392 \\
Cataluña & 6.2038 & 5.9285 & 5.6549 & 5.1793 & 4.6748 & 4.6817 & 4.9423 \\
Extremadura & 2.8893 & 2.7977 & 2.5744 & 2.6491 & 2.6215 & 2.2575 & 2.3097 \\
Galicia & 2.0376 & 2.0457 & 2.0573 & 2.1556 & 2.0864 & 1.9577 & 1.9211 \\
Madrid & 7.8307 & 7.7713 & 7.1916 & 7.3125 & 6.8395 & 6.0751 & 5.9143 \\
Murcia & 3.3951 & 3.3311 & 3.1846 & 3.1987 & 2.4746 & 2.1280 & 2.2337 \\
La Rioja & 4.2013 & 4.0757 & 4.0843 & 4.1827 & 3.6776 & 2.6112 & 2.6289 \\
Comunidad Valenciana & 2.6786 & 2.6877 & 2.6559 & 2.6497 & 2.4763 & 2.4443 & 2.4096 \\
Ceuta y Melilla & 2.3992 & 2.4288 & 2.4609 & 2.5337 & 2.4393 & 2.3725 & 1.8190 \\
\hline Spain (Common Territory) & 3.1084 & 3.1653 & 3.0826 & 3.4163 & 3.1154 & 2.8590 & 2.9031 \\
\hline Source: Own
\end{tabular}

Source: Own making on Cadastral Office (2006), Land Registry Office (2004) and Ministerio de Vivienda (2008).

Table 2

Effective coefficients for imputation applicable to cadastral values (Act 18/1991)

\begin{tabular}{llllllll}
\hline Autonomous Community & $\mathbf{1 9 9 2}$ & $\mathbf{1 9 9 3}$ & $\mathbf{1 9 9 4}$ & $\mathbf{1 9 9 5}$ & $\mathbf{1 9 9 6}$ & $\mathbf{1 9 9 7}$ & $\mathbf{1 9 9 8}$ \\
& & & & & & & \\
\hline Andalucía & 2.00 & 2.00 & 2.00 & 1.89 & 1.78 & 1.59 & 1.53 \\
Aragón & 2.00 & 2.00 & 2.00 & 1.93 & 1.86 & 1.33 & 1.31 \\
Asturias & 2.00 & 2.00 & 2.00 & 1.88 & 1.48 & 1.24 & 1.22 \\
Baleares & 2.00 & 2.00 & 2.00 & 1.80 & 1.62 & 1.28 & 1.24 \\
Canarias & 2.00 & 2.00 & 2.00 & 1.81 & 1.57 & 1.49 & 1.45 \\
Cantabria & 2.00 & 2.00 & 2.00 & 1.83 & 1.70 & 1.25 & 1.25 \\
Castilla y León & 2.00 & 2.00 & 2.00 & 1.77 & 1.40 & 1.31 & 1.27 \\
Castilla-La Mancha & 2.00 & 2.00 & 2.00 & 1.96 & 1.69 & 1.50 & 1.48 \\
Cataluña & 2.00 & 2.00 & 2.00 & 1.93 & 1.82 & 1.74 & 1.67 \\
Extremadura & 2.00 & 2.00 & 2.00 & 1.75 & 1.43 & 1.39 & 1.36 \\
Galicia & 2.00 & 2.00 & 2.00 & 1.87 & 1.77 & 1.57 & 1.50 \\
Madrid & 2.00 & 2.00 & 2.00 & 1.95 & 1.90 & 1.80 & 1.73 \\
Murcia & 2.00 & 2.00 & 2.00 & 1.89 & 1.85 & 1.65 & 1.65 \\
La Rioja & 2.00 & 2.00 & 2.00 & 1.98 & 1.90 & 1.41 & 1.39 \\
Comunidad Valenciana & 2.00 & 2.00 & 2.00 & 1.89 & 1.66 & 1.60 & 1.41 \\
Ceuta y Melilla & 2.00 & 2.00 & 2.00 & 2.00 & 2.00 & 2.00 & 1.51 \\
\hline Spain (Common Territory) & 2.00 & 2.00 & 2.00 & 1.89 & 1.73 & 1.59 & 1.52 \\
\hline
\end{tabular}

Source: Own making on Cadastral Office (2006). 
Table 3

Gross return rates of rental housing $\left(\omega_{j}\right)$

\begin{tabular}{llllllll}
\hline Autonomous Community & $\mathbf{1 9 9 2}$ & $\mathbf{1 9 9 3}$ & $\mathbf{1 9 9 4}$ & $\mathbf{1 9 9 5}$ & $\mathbf{1 9 9 6}$ & $\mathbf{1 9 9 7}$ & $\mathbf{1 9 9 8}$ \\
& & & & & & & \\
\hline Andalucía & 5.63 & 5.69 & 5.69 & 5.60 & 5.94 & 6.19 & 5.96 \\
Aragón & 5.96 & 6.17 & 6.42 & 6.61 & 7.03 & 7.51 & 7.01 \\
Asturias & 4.38 & 4.42 & 4.35 & 4.35 & 4.32 & 4.52 & 4.33 \\
Baleares & 6.27 & 6.30 & 6.19 & 6.16 & 6.37 & 6.36 & 5.48 \\
Canarias & 6.40 & 6.74 & 6.55 & 6.42 & 6.59 & 6.59 & 6.13 \\
Cantabria & 4.59 & 4.70 & 4.75 & 4.74 & 4.80 & 5.16 & 5.21 \\
Castilla y León & 3.77 & 3.88 & 3.95 & 3.96 & 4.24 & 4.34 & 4.31 \\
Castilla-La Mancha & 6.53 & 6.82 & 6.83 & 6.57 & 6.74 & 7.01 & 7.21 \\
Cataluña & 5.02 & 5.24 & 5.17 & 5.34 & 5.65 & 5.92 & 5.64 \\
Extremadura & 5.48 & 5.55 & 5.68 & 5.69 & 5.72 & 6.12 & 5.88 \\
Galicia & 4.24 & 4.32 & 4.29 & 4.15 & 4.34 & 4.52 & 4.49 \\
Madrid & 5.38 & 5.60 & 5.58 & 5.56 & 6.16 & 6.52 & 6.62 \\
Murcia & 5.53 & 5.77 & 5.94 & 5.91 & 6.05 & 6.10 & 5.99 \\
Navarra & 6.88 & 7.77 & 7.92 & 7.82 & 8.08 & 7.82 & 7.97 \\
País Vasco & 4.36 & 4.36 & 4.34 & 4.36 & 4.29 & 4.52 & 4.33 \\
La Rioja & 4.16 & 4.59 & 4.63 & 4.71 & 5.35 & 5.38 & 5.31 \\
Comunidad Valenciana & 6.78 & 6.78 & 6.78 & 6.90 & 7.09 & 7.21 & 6.83 \\
Ceuta y Melilla & n.a. & n.a. & n.a. & n.a. & n.a. & n.a. & n.a. \\
\hline Spain & 5.53 & 5.68 & 5.67 & 5.68 & 6.08 & 6.36 & 6.15 \\
\hline
\end{tabular}

Source: Own making on Ministerio de Vivienda $(2007,2008)$ and Consumer Prices Indexes (National Statistics Institute, INE)

Table 4

Imputed Income of Owner-Occupied Housing (average value in euros for taxpayer)

\begin{tabular}{|c|c|c|c|}
\hline Year & $\begin{array}{c}\text { Number of } \\
\text { taxpayers }\end{array}$ & $X_{i}^{N R H(C V)}$ & $X_{i, j}^{N R H(M V)}$ \\
\hline 1992 & 176,880 & 397.37 & $5,004.53$ \\
1993 & 186,660 & 428.11 & $5,445.43$ \\
1994 & 207,387 & 447.05 & $4,748.06$ \\
1995 & 212,786 & 392.64 & $4,811.92$ \\
1996 & 201,248 & 390.02 & $4,999.69$ \\
1997 & 213,808 & 390.10 & $5,270.02$ \\
1998 & 219,733 & 397.44 & $5,578.50$ \\
\hline
\end{tabular}

$X_{i}^{N R H(C V)}$ : Imputation at cadastral values in accordance with the Act 18/1991.

$\hat{X}_{i, j}^{N R H(M V)}$ : Imputation estimated at market values.

Source: Own making. 
Table 5

Imputed Income of Owner-Occupied Housing and Income before Tax (average value in euros for taxpayer)

\begin{tabular}{|c|c|c|c|c|c|}
\hline Year & $\begin{array}{c}\text { Number of } \\
\text { Taxpayers }\end{array}$ & $X_{i}^{N R H(C V)}$ & $\hat{X}_{i, j}^{N R H(M V)}$ & $X_{(\mathbf{a})}$ & $X_{(\mathbf{b})}$ \\
\hline 1992 & 276,446 & 254.25 & $3,205.73$ & $13,790.52$ & $16,685.36$ \\
1993 & 285,943 & 279.47 & $3,558, .72$ & $14,026.07$ & $17,244.62$ \\
1994 & 312,711 & 296.48 & $3,148.87$ & $14,219.53$ & $17,071, .06$ \\
1995 & 324,820 & 257.22 & $3,152.25$ & $14,623.56$ & $17,517.47$ \\
1996 & 310,381 & 252.89 & $3,241.76$ & $15,247.08$ & $18,234.86$ \\
1997 & 308,287 & 270.55 & $3,654.97$ & $15,859.81$ & $19,243.02$ \\
1998 & 308,141 & 283.41 & $3,977.99$ & $16,829.43$ & $20,522.86$ \\
\hline
\end{tabular}

$X_{i}^{N R H(C V)}$ : Imputation at cadastral values in accordance with the Act 18/1991.

$\hat{X}_{i, j}^{N R H(M V)}$ : Imputation estimated at market values.

$X_{(\mathrm{a})}$ : Income before tax including $X_{i}^{N R H(C V)}$

$X_{(\mathrm{b})}$ : Income before tax including $\hat{X}_{i, j}^{N R H(M V)}$

Source: Own making. 
Table 6. Income Inequality, Redistribution and Progressivity

Scenario 1: Imputation according to Act 18/1991

\begin{tabular}{|c|c|c|c|c|c|}
\hline Year & $G_{X}$ & $G_{Y}$ & $\Pi^{R S}$ & $\Pi^{K}$ & $a$ \\
\hline 1992 & 0.385526 & 0.342920 & 0.042606 & 0.273935 & 0.1365 \\
\hline 1993 & 0.391417 & 0.348398 & 0.043019 & 0.271286 & 0.1388 \\
\hline 1994 & 0.378303 & 0.335447 & 0.042856 & 0.267648 & 0,1400 \\
\hline 1995 & 0.381012 & 0.340111 & 0.040901 & 0.251385 & 0.1425 \\
\hline 1996 & 0.385538 & 0.343864 & 0.041674 & 0.277139 & 0.1327 \\
\hline 1997 & 0.386834 & 0.344811 & 0.042022 & 0.278472 & 0.1331 \\
\hline 1998 & 0.391368 & 0.348547 & 0.042821 & 0.280154 & 0.1346 \\
\hline
\end{tabular}

Source: Own making

Scenario 2: Imputation at market value, with exemption of valuation difference with respect to Act 18/1991

\begin{tabular}{|c|c|c|c|c|c|}
\hline Year & $G_{X}$ & $G_{Y}$ & $\Pi^{R S}$ & $\Pi^{K}$ & $a$ \\
\hline 1992 & 0.393775 & 0.364965 & 0.028809 & 0.235774 & 0.1126 \\
\hline 1993 & 0.399917 & 0.371021 & 0.028896 & 0.235520 & 0.1126 \\
\hline 1994 & 0.392800 & 0.363698 & 0.029102 & 0.228367 & 0.1166 \\
\hline 1995 & 0.386693 & 0.357038 & 0.029655 & 0.227133 & 0.1190 \\
\hline 1996 & 0.390220 & 0.360391 & 0.029830 & 0.247192 & 0.1110 \\
\hline 1997 & 0.389563 & 0.359921 & 0.029641 & 0.248910 & 0.1097 \\
\hline 1998 & 0.392209 & 0.361989 & 0.030220 & 0.252008 & 0.1103 \\
\hline
\end{tabular}

Source: Own making

Scenario 3: Imputation at market value and full inclusion in taxable income

\begin{tabular}{|c|c|c|c|c|c|}
\hline Year & $G_{X}$ & $G_{Y}$ & $\Pi^{R S}$ & $\Pi^{K}$ & $a$ \\
\hline 1992 & 0.393775 & 0.345309 & 0.048466 & 0.246051 & 0.1663 \\
\hline 1993 & 0.399917 & 0.349550 & 0.050367 & 0.246872 & 0.1713 \\
\hline 1994 & 0.392800 & 0.342947 & 0.049853 & 0.245682 & 0.1705 \\
\hline 1995 & 0.386693 & 0.340103 & 0.046590 & 0.230720 & 0.1705 \\
\hline 1996 & 0.390220 & 0.343910 & 0.046310 & 0.245587 & 0.1606 \\
\hline 1997 & 0.389563 & 0.342939 & 0.046624 & 0.243133 & 0.1628 \\
\hline 1998 & 0.392209 & 0.344960 & 0.047249 & 0.241700 & 0.1655 \\
\hline
\end{tabular}

Source: Own making 


\section{ANNEX I}

Table A.1.

Valuation of housing incomes and affected variables in empirical analysis

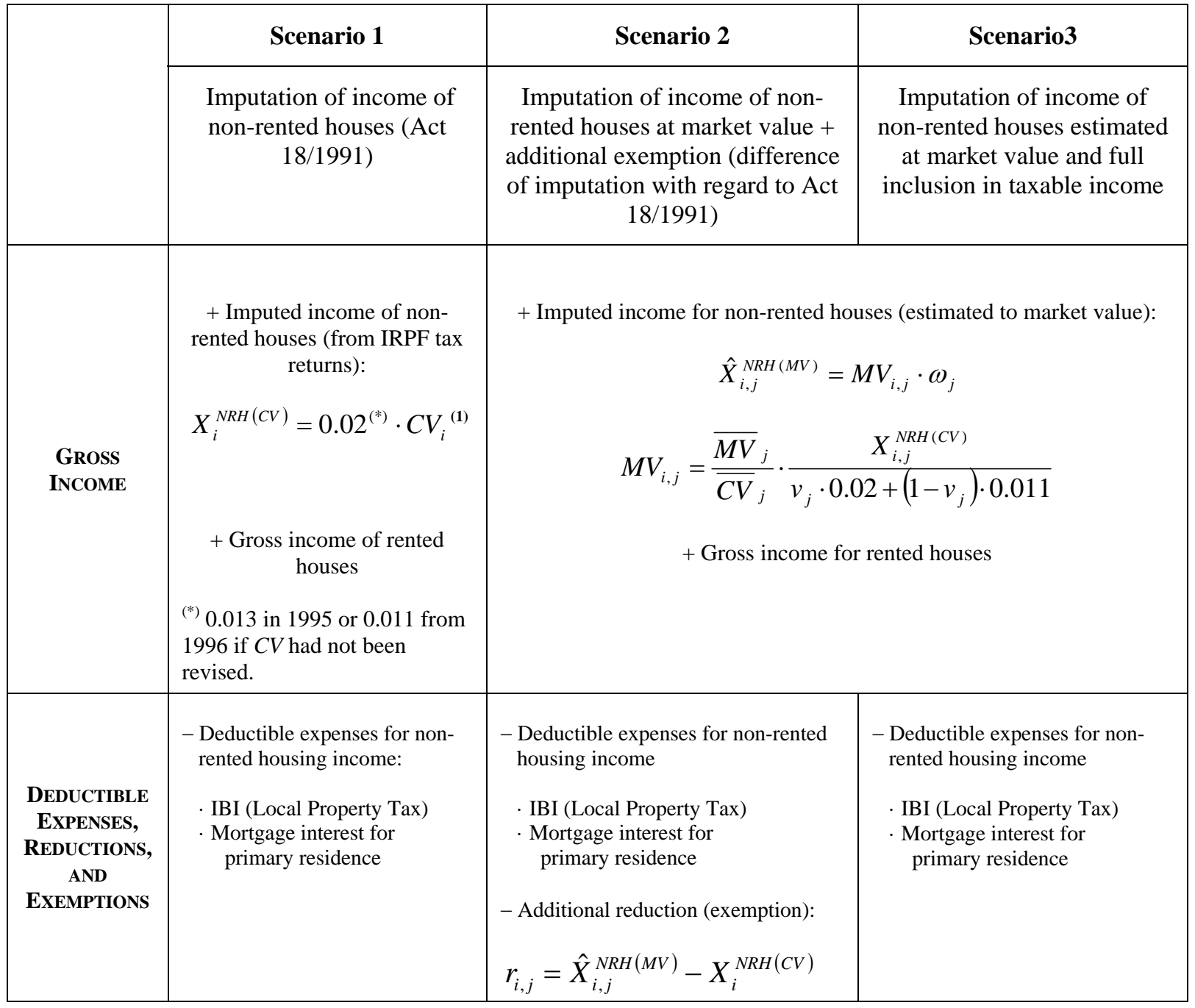

Source: Own making. 
Table A.2.

Treatment of non-rented owned housing in OCDE countries

\begin{tabular}{|c|c|c|}
\hline Germany & It is not imputed & $\begin{array}{l}\text { 1. Acquisition before } 1996 \text { (only taxpayers with } \mathrm{TB} \leq 61,355 € \text { and } \mathrm{TB} \leq 122,710 \\
\text { in joint declaration): a) first } 4 \text { years: deduction in TB of } 6 \% \text { of the cost (inc. } 50 \% \\
\text { of the land) with annual limit of } 10,124 € \text {; b) next } 4 \text { years: } 5 \% \text {, with annual limit } \\
\text { of } 8437 € \text {; c) additional deduction in annual amounts of } 512 € \text { per child. } \\
\text { 2. Acquisition after } 1996 \text { (only taxpayers with } \mathrm{TB} \leq 81,807 € \text { and } \mathrm{TB} \leq 163,614 \text { in } \\
\text { joint declaration): a) first } 8 \text { years: exempted transference of } 5 \% \text { of the cost } \\
\text { (inc. } 100 \% \text { of the land) with limit of } 2,556 € \text { per taxpayer (1250€); b) additional } \\
\text { deduction in annual amounts of } 767 € \text { per child that lives in the house. In this } \\
\text { case, the TB limit widens to } 30,678 € \text { per child. Application for only one housing } \\
\text { acquisition throughout life. }\end{array}$ \\
\hline Canada & It is not imputed & Do not exist \\
\hline Denmark & $\begin{array}{l}\text { It is not imputed (since } 2000 \text { it is } \\
\text { taxed on a Personal Property Tax) }\end{array}$ & Do not exist \\
\hline France & It is not imputed (since 1964) & Do not exist \\
\hline Greece & It is not imputed (since 2003) & Do not exist \\
\hline Ireland & It is not imputed (since 1970) & $\begin{array}{l}\text { In some cases, deductions are applied ( } 50 \% \text { of the building or renovation cost) in } \\
\text { protected or promoted areas. }\end{array}$ \\
\hline Italy & $\begin{array}{l}\text { It is imputed and grows in } 1 / 3 \text { if } \\
\text { there are additional houses. }\end{array}$ & Deduction of the imputed value \\
\hline Holland & $\begin{array}{l}\text { It is imputed according to an } \\
\text { estimated market value for rents. }\end{array}$ & $\begin{array}{l}\text { Personal deduction based on mortgage interests and other related expenditure } \\
\text { during a period of } 30 \text { years. If net imputed income negative, it is totally } \\
\text { deductible. }\end{array}$ \\
\hline Norway & It is not imputed (since 2005). & Do not exist \\
\hline Portugal & It is not imputed & Do not exist \\
\hline $\begin{array}{l}\text { United } \\
\text { Kingdom }\end{array}$ & It is not imputed (since 1963) & Do not exist \\
\hline
\end{tabular}

TB: Tax Base

Source: International Bureau of Fiscal Documentation (2008a,b). 